\title{
4 In(ter)dependent policies? Expert survey findings on relations between immigration and integration policies in selected EU member states
}

\author{
Marcin Gońda and Karolina Podgórska
}

\section{Introduction}

Immigration and integration policies are usually analysed as two separate spheres of a state's activity. This division is based on a conviction that actions performed under an integration policy and their effects have limited impact on regulations regarding the inflow of foreigners into a given state. Various research findings show, however, that there are relevant interdependencies between immigration and integration policies and that the scope of their connections largely determines a state's approach to immigration (cf. Hammar 1985a, 2010; Messina 2007). This means that the degree to which borders are open to immigrants could depend on the level of integration of those foreigners who already reside in that state (cf. Bosswick and Heckmann 2006). However, integration measures might also result from a state's admission practices. Immigration and integration policies counting among a state's public policies has a long tradition in migration analyses (cf. Geddes and Scholten 2016; Hammar 1985b; Penninx and Garcés-Mascareñas 2016; Schain 2008). This gained momentum during the so-called refugee crisis of 2015 , which resulted in a strong polarisation of political scenes and of Europeans' opinions regarding immigration (cf. Schain 2018). In the context of European migration challenges, there is a need to re-assess relations between both policies and their role in public policies of certain EU member states.

This chapter discusses the findings of an online Delphi-method-based survey conducted in 2017-2018 among diversified groups of experts on relations between immigration and integration policies in selected EU states. Among the nearly 80 respondents representing eight European states (Czechia, France, Germany, the Netherlands, Poland, Spain, Sweden and the United Kingdom) were local- and state-level policy-makers, researchers and members of NGOs. The survey's aim was to reconstruct experts' opinions on current and desirable links between the two policies and to collect their forecasts for the development of these policies in the next few years. Diverse factors influence both policies: historical, socio-economic, internal and foreign policies, as well as political philosophy or current social convictions. Various entities and interest groups of different levels - including international institutions but also politicians, officials, employers or social 
organisations - also affect their formation (Natter 2018). In this context the following questions emerge:

- What determines the shape of these two areas of public policy in particular EU states?

- What are the relations between them?

- What are the dynamics of these changes in recent years in a situation of growing reluctance towards immigrants and the politicisation of the immigration issue?

- Considering the increasing attention paid by Europeans to immigration, what are the future scenarios for the development of the two policies as foreseen by experts?

\section{Research methodology}

In order to face the challenge of describing the current shape of immigration and integration policies and of anticipating their future development in the European countries investigated, the IMINTEG research team carried out a comparative study using the Delphi method. ${ }^{1}$ On this basis the team sought the opinions of a deliberately chosen panel of experts on a subject requiring complex and barely accessible knowledge - used mostly to assess trends in the development of given phenomena (Linstone and Turoff 1975; Martino 1972). In subsequent rounds of the study, a version of the questionnaire was used which was extended by the presentation of the results from the previous round. This allowed anonymous participants to compare their own answers and, as a result, change or maintain their opinion on a given issue. This procedure also enables researchers to sift through the various opinions, rejecting those which are extreme and atypical, until a uniform statement of experts is achieved (Drbohlav 1997). Rather than obtaining numerous and therefore separate opinions, it is important to gather fewer but more in-depth ones that lead to a consensus on a given issue in the course of subsequent research phases. The Delphi method is currently used to predict phenomena of high social significance - for instance public health, education or environmental protection. It is also gaining increasing popularity in migration analyses (see Bijak and Wiśniowski 2009; Jaroszewicz and Lesińska 2014; Lachmanová and Drbohlav 2004).

The online Delphi survey was conducted in two rounds in the autumn of 2017 and the spring of 2018. In the first round, the online questionnaire was distributed to more than 200 experts from eight EU member states. In total 79 experts responded, who were then approached again in the second round. In the end, answers from 56 experts were collected (see Table 4.1). In our analysis we focus on two axes of interpretation of the data collected. First, the countries were chosen to take into account the differentiation in immigration and integration policy models and, in consequence, their position on an historical map of European population transfers. We decided to cluster the data from the eight states into two blocks representing the two stages of immigration phenomena in Europe. The first block 
Table 4.1 Structure of the panel of experts

\begin{tabular}{|c|c|c|c|c|c|}
\hline & \multirow{2}{*}{$\begin{array}{l}\text { Researchers } \\
(R E)\end{array}$} & \multicolumn{3}{|c|}{ Policy-Makers and Practitioners } & \multirow{2}{*}{$\begin{array}{l}\text { Total by } \\
\text { Country }\end{array}$} \\
\hline & & $\begin{array}{l}\text { Central } \\
\text { administration } \\
(A C)\end{array}$ & $\begin{array}{l}\text { Local } \\
\text { administration } \\
(A L)\end{array}$ & $\begin{array}{l}\text { Nongovernmental } \\
\text { organisations } \\
\text { (NGOs) }\end{array}$ & \\
\hline \multicolumn{6}{|l|}{ Round I } \\
\hline Germany (DE) & 5 & 4 & 1 & 2 & 12 \\
\hline France (FR) & 3 & 2 & 0 & 0 & 5 \\
\hline $\begin{array}{l}\text { The Netherlands } \\
\text { (NL) }\end{array}$ & 4 & 1 & 0 & 0 & 5 \\
\hline Spain (ES) & 7 & 0 & 2 & 1 & 10 \\
\hline Sweden (SE) & 6 & 0 & 1 & 4 & 11 \\
\hline $\begin{array}{l}\text { United } \\
\text { Kingdom } \\
\text { (UK) }\end{array}$ & 4 & 0 & 0 & 1 & 5 \\
\hline Czechia (CZ) & 4 & 4 & 0 & 6 & 14 \\
\hline Poland (Pl) & 6 & 5 & 3 & 3 & 17 \\
\hline $\begin{array}{l}\text { TOTAL (by } \\
\text { employment } \\
\text { sector) }\end{array}$ & 39 & 16 & 7 & 17 & 79 \\
\hline \multicolumn{6}{|l|}{ Round II } \\
\hline Germany (DE) & 2 & 1 & 0 & 2 & 5 \\
\hline France (FR) & 3 & 1 & 0 & 0 & 4 \\
\hline $\begin{array}{l}\text { Netherlands } \\
\text { (NL) }\end{array}$ & 2 & 1 & 0 & 0 & 3 \\
\hline Spain (ES) & 3 & 2 & 0 & 1 & 6 \\
\hline Sweden (SE) & 4 & 1 & 0 & 0 & 5 \\
\hline $\begin{array}{l}\text { United } \\
\text { Kingdom } \\
\text { (UK) }\end{array}$ & 3 & 0 & 0 & 0 & 3 \\
\hline Czechia (CZ) & 3 & 4 & 0 & 6 & 13 \\
\hline Poland (PL) & 6 & 5 & 3 & 3 & 17 \\
\hline $\begin{array}{l}\text { TOTAL (by } \\
\text { employment } \\
\text { sector) }\end{array}$ & 26 & 15 & 3 & 12 & 56 \\
\hline
\end{tabular}

consists of states with a long immigration tradition, including those with a postcolonial history (France, the Netherlands, the United Kingdom) and those experiencing mass postwar labour immigration as well as recent refugee immigration (Germany, Spain, Sweden). The second block is made up of new immigration destinations (Czechia, Poland). This distinction also comprises an overlap between Western Europe and Central Europe. The proposed interpretation scheme allows us to observe potential approaches to the relations between immigration and integration policies in the context of clashes between old and new migration patterns.

Secondly, the group of respondents contained representatives of four sectors: researchers from academia and scientific entities (hereinafter marked as RE), 
policy-makers from central (AC) and local administration (AL) as well as practitioners working in nongovernmental sectors (NGO). For this chapter, special attention was paid to the comparison between the academic (theoretical) point of view and the practical one represented by policy-makers and practitioners. Such an approach cannot easily be found in the existing literature but is crucial for pinpointing the potential inconsistencies in the European debate on immigration and integration policies. Consequently, the answers collected among researchers (39 in the first round and 26 in the second) were compared to the responses of the aggregated group of policy-makers of central and local administration and NGO practitioners (40 in the first round and 30 in the second round). On the other hand, in total 48 and 26 answers (in the first and second round, respectively) were gathered from respondents in Western European states (Germany, France, the Netherlands, Spain, Sweden, the United Kingdom), whereas Central and Eastern Europe were represented by 31 and 30 (in the first and second rounds, respectively) Polish and Czech respondents. The experts in the first round had an average of over 13 years of professional experience (nearly 15 years in the researchers' group and almost 12 years among policy-makers and practitioners), while those answering the second-round questionnaire had been dealing professionally with migration issues for about 15 years (18 for researchers and 13 for practitioners).

The main challenge in the organisation of the Delphi survey was to find a sufficient number of experts within each predefined group in all the states being researched and to maintain constant respondent representation between the two rounds. Despite the IMINTEG research team's efforts to secure an equal number of respondents in each category, the most underrepresented subcategory was that of local administration employees. We think there are two reasons for this. The first is the position of immigration/integration policies in the local context - for example, in the United Kingdom, responsibility for local activities in migration issues were delegated to NGOs whereas, in France, migration policy is traditionally highly centralised (Scholten and Penninx 2016: 99). The second reason is because we encountered difficulties in recruiting relevant respondents - local officials dealing precisely with immigration/integration issues, for example. Surprisingly, it was also hard to reach selected experts from the 'core' migration countries: France, the Netherlands and the United Kingdom, where the number of research centres on migration problems is extremely high.

The survey included 16 closed questions referring to three main topics: immigration policy; integration policy towards migrants; relations between these two state activities. The last set of questions concerned the linkages between immigration and integration policies and factors shaping them in three periods (during the five years prior to the survey, at the moment of the survey and within the following five years) as well as in the desired situation (optimal for the state's interest). In addition, we asked about the impact of EU institutions on the implementation of these two spheres. Although the survey did not directly refer to refugee and asylum policies, it was conducted at the time of the European refugee crisis, which might have influenced respondents' opinions. As we were aware of this, we asked the experts, in the methodological instructions, to focus on the broader and 
longer-term perspective rather than the present migration situation of their respective countries. Nonetheless, since the experts, apart from answering the closed questions, also had the opportunity to add comments to the issue, they still underlined the challenges their countries had faced at the time of the refugee crisis.

In the questionnaire, we also included definitions of the policies being investigated. As stated in the introduction to this book, the principles and scope of a state's actions towards migration are variously described in the migration literature (cf. Boswell 2006; Brochmann and Hammar 1999; Dell'Olio 2004; Duszczyk 2008; Zapata-Barrero et al. 2017). The legal acts and/or practices of particular states also define them in different ways. For the IMINTEG project, we conceptualised immigration policy as the action taken by a state to control the rules of entry and stay on its territory of people who are not citizens of that state. We perceived integration policy as the action taken by a state to ensure a dynamic, two-way process of mutual adjustment between immigrants and the receiving society (for more on this, see Chapter 2).

In the rest of this chapter we focus only on those selected results of the survey that directly refer to the different relations between immigration and integration policies. In detail, we present expert assessments on current (answers to Q11) and desirable (Q12) relations between the two policies in particular EU states, as well as the experts' predictions regarding the direction(s) which these two policies are likely to take in the future (Q13). We show the quantitative distribution of responses, deepened by qualitative analysis of the experts' comments (highlighted in italics). The results of the second round of our study (56 expert responses in total) are presented. Where the opinions of experts were significantly different between the two rounds, we present the results of both research stages.

\section{Current relations between immigration and integration policies}

First the respondents were asked to describe the current relationship between immigration and integration policies in their countries (see Table 4.2). Irrespective of the experts' sector of professional engagement as well as the history of immigration to their countries, the vast majority of the participants noted that the two policies being investigated were interconnected but that immigration policy played the dominant role. For instance, all four French and all four Dutch survey participants saw the dominance of immigration policy over integration policy. We may assume, then, that they agreed that the integration of foreigners was subordinate to a state's migrant admission policy, as a state normally needs first to respond to the arrival of migrants before, subsequently, implementing integration measures step by step, as indicated by this Czech respondent:

It is a question of building a 'foreigners' infrastructure. Immigration policy has been dealt with as a priority; integration policy has established itself gradually, slowly and with difficulty. As a younger and somewhat forced guide. 
Table 4.2 Responses to Q11: 'Please select the statement below which best describes the relations between your country's current immigration and integration policies'

\begin{tabular}{|c|c|c|c|c|}
\hline \multicolumn{5}{|l|}{ Round II } \\
\hline & Researchers & $\begin{array}{l}\text { Policy- } \\
\text { Makers and } \\
\text { Practitioners }\end{array}$ & $\begin{array}{l}\text { Western Europe } \\
\text { (DE, FR, NL, } \\
\text { ES, SE, UK) }\end{array}$ & $\begin{array}{l}\text { Central and } \\
\text { Eastern Europe } \\
(C Z, P L)\end{array}$ \\
\hline $\begin{array}{l}\text { Policies are implemented } \\
\text { independently } \\
\text { (decisions taken } \\
\text { in migration and } \\
\text { integration policy are } \\
\text { not interrelated) }\end{array}$ & 6 & 1 & 4 & 3 \\
\hline $\begin{array}{l}\text { Policies related but } \\
\text { immigration policy } \\
\text { plays dominant } \\
\text { role (integration } \\
\text { policy decisions are } \\
\text { a consequence of } \\
\text { immigration policy } \\
\text { decisions) }\end{array}$ & 18 & 22 & 18 & 22 \\
\hline $\begin{array}{l}\text { Policies related but } \\
\text { integration policy } \\
\text { plays dominant } \\
\text { role (immigration } \\
\text { policy decisions are } \\
\text { a consequence of } \\
\text { integration policy } \\
\text { decisions) }\end{array}$ & 0 & 0 & 0 & 0 \\
\hline $\begin{array}{l}\text { Policies are implemented } \\
\text { jointly, but it is difficult } \\
\text { to say which one plays } \\
\text { the dominant role }\end{array}$ & $t^{0}$ & 7 & 4 & 3 \\
\hline $\begin{array}{l}\text { Other situation (please } \\
\text { specify) }\end{array}$ & 2 & 0 & 0 & 2 \\
\hline TOTAL & 26 & 30 & 26 & 30 \\
\hline
\end{tabular}

One of the British experts bitterly underlined the actual dominance of immigration policy in the UK which resulted from a lack of adequate social policy instruments in the field of migrants' integration:

The 'needs of industry' should not be prioritised over integration measures; at the moment they are. But 'integration' also needs to include the provision of housing, school places, health and other services and these have to expand to the meet the needs of a larger population - this has not been the case. 
Only in a few cases did the experts tend to see a lack of connection between these policies or, on the contrary, their simultaneous implementation without the possibility of determining the precedence of one over another. This last idea is described here by another Czech expert:

In my opinion, the Policy for the Integration of Immigrants is integral to legal migration, to which it must be directly linked. Successful integration is a direct prerequisite for the expediency and efficacy of migration. The integration policy is based on experience - that preventing problems in co-existence is always easier than facing the consequences of ill-handled integration.

(II_CZ_3_AC)

The latter opinions were delivered mostly by policy-makers and practitioners (from Czechia, Germany, Spain and Sweden) and contradicts the stances taken by researchers who - besides their still-dominant opinion on the leading role of immigration policy - also specified that the two policies are unrelated and implemented separately.

What needs to be emphasised is that, whereas in the first round of the Delphi survey few respondents placed integration measures over immigration policy and justified this point of view with 'Language capabilities and job offers play a major role in decisions on immigration policy' (I_DE_1_NGO) - none of the experts in the second round prioritised integration policy over immigration policy. This proves that the Delphi survey procedure enables researchers to settle for more uniform statements and to reject opinions that seem to be unreal and atypical.

Interesting comments on the issues being investigated were also given by the Polish experts. They refused to clearly determine the relationship between Poland's immigration and integration policies since, as one of them argued, 'integration policy basically does not exist' (II_PL_3_RE). They underlined that statecentric integration measures are limited to education (foreign children are subject to compulsory schooling) whereas, in practice, one Polish expert posited that:

all (integration) activities are undertaken by NGOs and financed from external sources and integration strategies appear at the level of cities, where activities are financed from the communal budget.

What is more, due to the lack of mature immigration and integration solutions, these policies overlapped or were even contradictory, as another Polish expert confirmed:

There are dependencies between them but, at the same time, immigration policy plays a leading role. Nevertheless, integration activities are happening independently and even contrary to what emerges from immigration policy. 
Consequently, it is not possible to indicate any current dependencies between these two spheres of a state's activity (cf. Gońda and Klaus 2018). What needs to be underlined is that these critical opinions were expressed by two academics (researchers) and one central administration officer. On the other hand, civil servants also tended to look for excuses regarding the lack of integration tools (and, thus, found no relation between the two types of policy). One of the Polish respondents argued that:

Institutions responsible for integration policy have until now conditioned the adoption of (conceptual) measures on migration policy, based on the principle: 'If there is no migration policy, then we do not have to create an integration policy'.

(II_PL_16_AC)

\section{The desired relationship between immigration and integration policies}

Besides determining the contemporary relationship between immigration and integration policies in each of the eight EU states, the experts were also asked to discuss how they would prefer to see the connections between these two spheres of state activity - in other words, how should this relationship look, taking into account a given state's interests and characteristics (see Table 4.3). What should be strongly stressed is that almost all respondents from both participant groups distinctly agreed that, contrary to the present policy practices of European states, immigration and integration policies should be implemented jointly and simultaneously. The experts underlined the fact that, as far as decisions on the scale of immigration and the scope of integration activities were concerned, they needed to be part of one decision-making process. Interestingly, there were no discrepancies in this domain between the experts' professional backgrounds or their countries of residence. Furthermore, what makes the present and desired relationship between the policies we are investigating even more pronounced was that today's precedence of immigration over integration policies would be favourable only for one respondent. No significant differences in the distribution of answers to this multiple issue were noted between the two rounds of the Delphi survey, which proved that the experts already had grounded and well-established visions of how adequate immigration/integration policies should be.

\section{The predicted relationship between immigration and integration policies five years from now}

Finally, the experts gathered for the Delphi survey were asked how they foresaw the future development of the two policies and their mutual dependency (see Table 4.4). Interestingly, when it comes to the relationship between immigration and integration policies in the next five years, the predicted scenarios varied 


\section{Marcin Gońda and Karolina Podgórska}

Table 4.3 Responses to Q12: 'Based on your own knowledge and experience, please select the statement below which best describes the desired relations between immigration and integration policies in your country'

\begin{tabular}{|c|c|c|c|c|}
\hline \multicolumn{5}{|l|}{ Round II } \\
\hline & Researchers & $\begin{array}{l}\text { Policy- } \\
\text { Makers and } \\
\text { Practitioners }\end{array}$ & $\begin{array}{l}\text { Western Europe } \\
(D E, F R, N L, \\
E S, S E, U K)\end{array}$ & $\begin{array}{l}\text { Central and } \\
\text { Eastern Europe } \\
(C Z, P L)\end{array}$ \\
\hline $\begin{array}{l}\text { The two policies should } \\
\text { be implemented } \\
\text { independently }\end{array}$ & 1 & 0 & 1 & 0 \\
\hline $\begin{array}{l}\text { Immigration policy } \\
\text { should determine } \\
\text { integration policy } \\
\text { (integration policy } \\
\text { decisions should } \\
\text { depend on the scale of } \\
\text { the influx of foreigners } \\
\text { arriving for different } \\
\text { reasons) }\end{array}$ & 0 & 1 & 0 & 1 \\
\hline $\begin{array}{l}\text { Integration policy should } \\
\text { determine immigration } \\
\text { policy (decisions } \\
\text { concerning the scale } \\
\text { of immigration and the } \\
\text { duration of migrants' } \\
\text { stay should depend on } \\
\text { the effectiveness of } \\
\text { integration policy) }\end{array}$ & 1 & 2 & 1 & 2 \\
\hline $\begin{array}{l}\text { The two policies should } \\
\text { be implemented jointly } \\
\text { and simultaneously } \\
\text { (decisions on the scale } \\
\text { of immigration and the } \\
\text { scope of integration } \\
\text { activities should be } \\
\text { taken as part of a } \\
\text { single process) }\end{array}$ & 24 & 27 & 24 & 27 \\
\hline $\begin{array}{l}\text { Other situation (please } \\
\text { specify) }\end{array}$ & 0 & 0 & 0 & 0 \\
\hline TOTAL & 26 & 30 & 26 & 30 \\
\hline
\end{tabular}

more than did those observed today or those desired by the respondents. Despite the majority of respondents, in particular those from Central Europe, still seeing the dominant role played by immigration policy (and, thus, integration policy being dependent on the scale of the immigrant influx and the duration of the foreigners' stay) as the most probable in the future, several researchers and policymakers/practitioners also predicted that the two policies would be implemented 
Table 4.4 Responses to Q13: 'What do you expect the relations between immigration and integration policies in your country to be like over the next five years?'

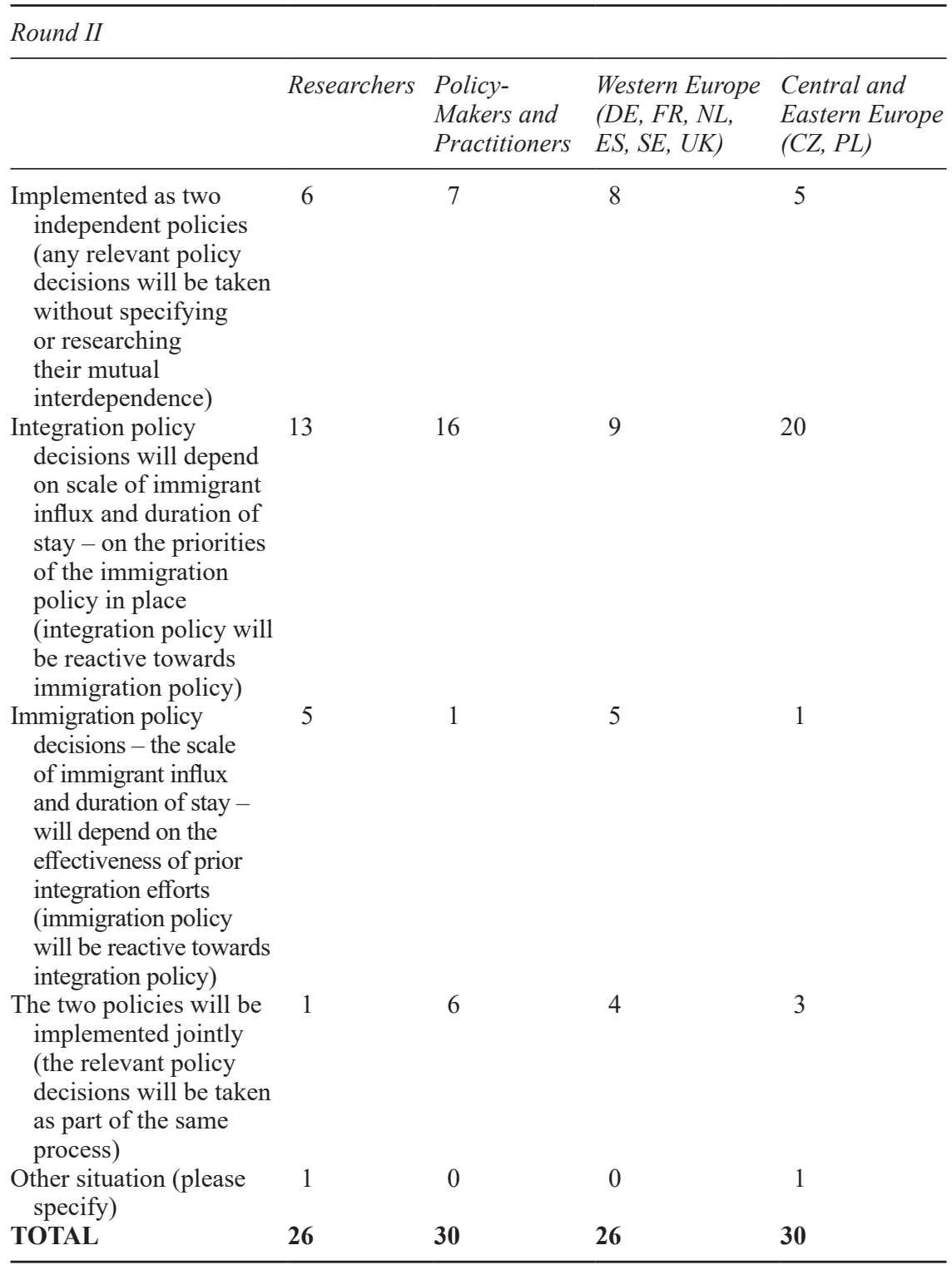

independently. Although the forecasts delivered by Western European respondents were, in general, very dispersed, they were particularly eager to anticipate such a scenario. Furthermore, a few researchers agreed that immigration policy would be reactive towards integration policy, whereas the majority of policy-makers/ practitioners also predicted that both policies would be implemented as part of 
the same decision-making procedure. One of the German experts interviewed was confident about the latter scenario:

As in the current situation, the two policies are implemented jointly and, in the case of a growing immigrant influx, both policies will be changed or adapted jointly.

(II_DE_3_NGO)

One respondent also pointed to another possible situation but, like the opinions already expressed in the question on the current relations between the two policies, it was a pessimistic conclusion that one of these two policies (integration policy) 'does not exist' (II_PL_3_RE). Like the issue - discussed earlier - of desired immigration and integration polices, no significant differences in predictions were observed between the first and second round of the Delphi survey. We may again assume that the experts were stable and realistic as to the development of both policies.

\section{Conclusions}

Our findings from the Delphi survey conducted among European experts on migration issues showed that perceptions of the current and future development of relations between immigration and integration policies were not specifically dependent on their state context: despite contradictory macrostructural conditions (particular states' immigration histories, political profiles, modes of creation and implementation of public policies and coherent visions nor any clearly defined objectives for either policy) and the evaluation of immigration (less or more restrictive) and integration policy (less or more effective), ${ }^{2}$ similar opinions on relations between the policies now and prospects for the next five years were observed. Table 4.5 presents the main axes of experts' stances on all the questions in the survey:

Table 4.5 Relationship between policies (aggregated findings)

\section{WHAT DOES IT LOOK LIKE?}

Dominant role of immigration policy

WHAT SHOULD IT LOOK LIKE?

Should be implemented simultaneously and jointly (one decision-making process)

WHAT WILL IT LOOK LIKE IN 5 YEARS?

\begin{tabular}{llll} 
Researchers & $\begin{array}{c}\text { Policy-makers and } \\
\text { practitioners }\end{array}$ & $\begin{array}{l}\text { Western Europe } \\
\text { (DE, FR, NL, ES, }\end{array}$ & $\begin{array}{c}\text { Central and Eastern } \\
\text { Europe } \\
\text { (CZ, PL) }\end{array}$ \\
$\begin{array}{l}\text { Dominant role of immigration policy } \\
\text { (half of the responses in each group) }\end{array}$ & $\begin{array}{l}\text { Different approaches } \\
\text { (all scenarios) }\end{array}$ & $\begin{array}{l}\text { Dominant role of } \\
\text { immigration policy }\end{array}$ \\
\hline
\end{tabular}


When trying to conclude the results of the survey's second round, we found that it was worth combining three modes enabling us to understand the relationship between immigration and integration policies. In general, regardless of the field of expertise and state affiliation, our respondents indicated that the current relationship between the policies was marked by the dependence of integration activities on directions for the implementation of immigration policy. As was distinctly expressed by one Delphi panelist from Czechia:

Immigration policy is naturally in the lead but must be done with a thorough understanding of the socio-cultural context, and must be immediately followed by integration measures.

(I_CZ_9_NGO)

At the same time, the experts agreed that the ideal relationship between these two policies should have been founded on their interdependence - i.e. a situation when decisions undertaken within each of them were part of the joint decisionmaking process and were complementary to each other. The opinions of our panel of experts in this respect were well grounded and stable, since the vast majority of them in the first round of the survey also tended to agree with these scenarios.

Slightly more diverse responses were noted when it came to the key issue of forecasting the future developments of the two policies and their relationship. Half of the respondents representing both the group of researchers and that of policy-makers/practitioners indicated that, within the next five years, the state of dependence between the two policies would remain the same as today - i.e. integration practices would be determined by a state's migration admission policy. The prospects for other scenarios were less probable, with some likelihood that the two policies would be implemented independently (any relevant policy decisions would be undertaken without specifying their mutual interdependence). Interestingly, however, the belief that immigration policy would be still dominant was particularly popular among the experts from Czechia and Poland - which are currently transforming from emigration to immigration countries. In West European countries that have both greater experience in managing large waves of migration and better developed practices for newcomers' integration, the responses were spread in a more diverse way. However, what needs to be distinctly underlined is that none of the experts gave the priority to integration policy over immigration policy; thus, based on the results of our study, this scenario would seem to be totally unlikely. It is also worth noting that, despite the assumed 'natural' diversity in the stances taken by scientists on the one hand and people directly involved in the implementation of specific policy solutions on the other, the opinions of the experts and practitioners in our study proved to be quite consistent. Just as with the whole group of experts, the biggest discrepancies were observed when assessing the shape of any future relationship between immigration and integration polices. Both groups of respondents agreed on their assessment of the current situation and indicated similar ideal scenarios for these policies' future development. 
The prognosis for the development of relations between integration and immigration policies in the future turned out, then, to be inconsistent with the situation which, as the experts suggested, would be the most favourable for the European states in our study. Only a few respondents indicated that, in the short term, an ideal scenario would be found - both policies would be interdependent and developed complementarily. It is perhaps worth asking why half of the experts who participated in our Delphi survey, who came from various professional backgrounds, thought that the current relationship between policies (with the dominant role of immigration policy) would prevail over the next five years. Why did not they take into account what they themselves deemed to be the ideal and thus optimal scenario of the interdependence of these two policies? Both categories of expert, irrespective of their country background, appeared to be very pragmatic and, based on their expertise in the development of national policies as well as particular societies' responses to the recent refugee crisis, perceived this scenario as fundamentally improbable. The following two opinions, by a Spanish and a Dutch expert respectively, reflect their realistic approach in this domain:

The two policies will be implemented separately. Nevertheless, they are actually deeply interconnected, so a joint implementation is strongly desirable.

(I_ES_3_RE)

[Joint implementation] sounds ideal but, in practice, immigration policy always takes priority over integration policy, especially when the former aims at restrictiveness. Therefore, the other option [that immigration policy should determine integration policy] is more realistic.

Our study does not, then, bring a clear answer to our research questions but would appear to be a good starting point for further analysis. It seems that the expert outlook presented to us on the relationship between immigration and integration policies was framed by the proposed short time frame - five years is not a lot of time in which to change the modes or directions of public policies (none of the experts suggested such a circumstance, though). On the other hand, given the dynamic migration situation in Europe in recent years, stable expert opinions on the lack of change in the functioning of these two policies may have been an expression of their concerns about growing migration challenges in Europe framed by categories of securitisation and threats - and the emphasis on border protection. The compatibility of these expert opinions may also have been connected with the impact of according priority to the development of EU migration and asylum policies.

\section{Notes}

1 The field research was conducted by Marcin Gońda and Karolina Podgórska as part of the IMINTEG - 'in search for models of relations between immigration and integration policies' project implemented at the Centre of Migration Research, University of 
Warsaw. The project was financed by the Polish National Science Centre (grant agreement No. 2014/14/E/HS5/00397). The research team, apart from the authors of this chapter, included Maciej Duszczyk (head), Witold Klaus, Magdalena Lesińska, Marta Pachocka, Dominika Pszczółkowska and Dominik Wach, whom we thank for their valuable input to this text.

2 In the survey we also assumed the outcome (or the lack) of the implementation of the two policies, understood as follows: an ineffective integration policy - immigrants do not integrate at all and social tensions caused by their lack of integration are on the increase; effective integration policy - immigrants integrate very well and their presence and everyday activities do not give rise to any major social tension; a very restrictive immigration policy - the so-called closed door policy; and a non-restrictive immigration policy - the so-called open door policy.

\section{References}

Bijak, J. and Wiśniowski, A. (2009) Forecasting of Immigration Flows for Selected European Countries Using Expert Information. Warsaw: Central European Forum for Migration and Population Research, CEFMR Working Paper No. 1.

Bosswick, W. and Heckman, F. (2006) Integration of Migrants: Contribution of Local and Regional Authorities. Dublin: EUROFUND.

Boswell, C. (2006) The Political Uses of Expert Knowledge: Immigration Policy and Social Research. Cambridge: Cambridge University Press.

Brochmann, G. and Hammar, T. (eds) (1999) Mechanisms of Immigration Control: A Comparative Analysis of European Regulation Policies. Oxford: Berg.

Dell'Olio, F. (2004) 'Immigration and immigrant policy in Italy and the UK: Is housing policy a barrier to a common approach towards immigration in the EU?', Journal of Ethnic and Migration Studies, 30(1): 107-128.

Drbohlav, D. (1997) 'Migration policy objectives for European East-West international migration', International Migration, 35(1): 85-108. Available at https://doi. org/10.1111/1468-2435.00005.

Duszczyk, M. (2008.) 'Wyzwania polskiej polityki migracyjnej a doświadczenia międzynarodowe', in Kaczmarczyk, P. and Okólski, M. (eds) Polityka Migracyjna Jako Instrument Promocji Zatrudnienia i Ograniczania Bezrobocia. Warsaw: OBM WNE UW, pp. 11-20.

Geddes, A. and Scholten, P. (2016) The Politics of Migration and Immigration in Europe. London: Sage.

Gońda, M. and Klaus, W. (2018) 'Czynniki kształtujące polskie polityki imigracyjną i integracyjną w opinii badaczy i praktyków’, Polityka Społeczna, 11-12(536-537): 16-23.

Hammar, T. (1985a) 'The policymaking process', in Hammar, T. (ed.) European Immigration Policy. A Comparative Study. Cambridge: Cambridge University Press, pp. 277-291.

Hammar, T. (1985b) European Immigration Policy: A Comparative Study. Cambridge: Cambridge University Press.

Hammar, T. (2010) 'Introduction to European immigration policy: A comparative study', in Martiniello, M. and Rath, J. (eds) Selected Studies in International Migration and Immigrant Incorporation. Amsterdam: Amsterdam University Press, pp. 45-58.

Jaroszewicz, M. and Lesińska, M. (eds) (2014) Forecasting Migration between the EU, V4 and Eastern Europe. Impact of Visa Abolition. Warsaw: Ośrodek Studiów Wschodnich im. Marka Karpia.

Lachmanová, L. and Drbohlav, D. (2004) 'The probable future development of European East-West migration (Delphi method revived)', European Spatial Research and Policy, 11(1): 135-155. 


\section{Marcin Gońda and Karolina Podgórska}

Linstone, H. and Turoff, M. (eds) (1975) The Delphi Method: Techniques and Applications. Reading: Addison-Wesley.

Martino, J.P. (1972) Technological Forecasting for Decision Making. New York: American Elsevier.

Messina, M.A. (2007) The Logics and Politics of Post-World War II. Migration to Western Europe. Cambridge: Cambridge University Press.

Natter, K. (2018) Immigration Policy Theory: Thinking Beyond the 'Western LiberalDemocratic'Box. Oxford: University of Oxford, IMI Working Paper No. 145.

Penninx, R. and Garcés-Mascareñas, B. (2016) 'The concept of integration as an analytical tool and as a policy concept', in Garcés-Mascareñas, B. and Penninx, R. (eds) Integration Processes and Policies in Europe. Contexts, Levels and Actors. Heidelberg/New York/Dordrecht/London: Springer, pp. 11-30.

Schain, M.A. (2008) The Politics of Immigration in France, Britain and the United States: A Comparative Study. Basingstoke: Palgrave Macmillan.

Schain, M.A. (2018) Shifting Tides: Radical-Right Populism and Immigration Policy in Europe and the United States. Washington, DC: Migration Policy Institute. Available at www. migrationpolicy.org/sites/default/files/publications/Schain-PopulismUSandEuropeFinal-Web.pdf (accessed 29 August 2019).

Scholten, P. and Penninx, R. (2016) 'The multilevel governance of migration and integration', in Garcés-Mascareñas, B. and Penninx, R. (eds) Integration Processes and Policies in Europe. Contexts, Levels and Actors. Heidelberg/New York/Dordrecht/London: Springer, pp. 91-108.

Zapata-Barrero, R., Caponio, T. and Scholten, P. (2017) 'Theorizing the "local turn" in a multi-level governance framework of analysis: A case study in immigrant policies', International Review of Administrative Sciences, 82(2): 241-246. 